\title{
11. 铁遗及ひ铁造事轌
}

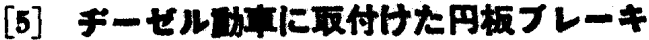

[Röbling, Organ f. Fortschr. d. Eisenbahnw., 1938-5 15, Jg.93, Ht. 10, 頁 197〜198, 因 4] 鉄道車㕲に 円板ブレ 一キを取付けた例は既に Henschel-Wegmann 蒸气列革や 二三の彭車に見られるが、独逻国有鉄道で は新設計の ヂーゼル水力式展望㽖車 に第 14 図に示す様な特殊の 円板ブレーキ を装 備してるる。

円板ブレーキはその構造上、装网全体の 占める埋所が狹くて済さから動力台車にも 比较的容易に充分に场所の余裕を作つて配

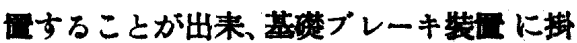

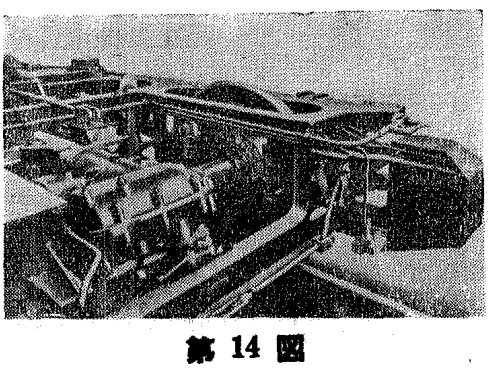

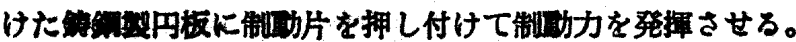

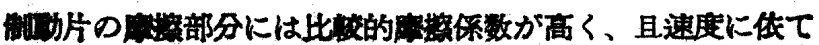

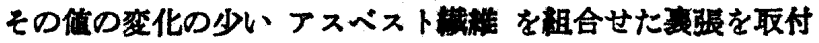
けてるる。張は中空の アルミニウム鋲で表張支持片に固 定し、この支持片は ありざしに依て制野片体に取付けてあ ろから非の場合简單に取换へろことが出 来る。円板は ボルトで輪心に取付け、外 周に近い所にノックを設けて內外の円板

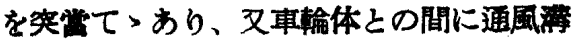
を設けてあるから運轉中、空气の流が起つ てブレーキの带熱を冷却すら構造になつ てふな。第16因は合車全体の 基碳ブレ一 キ装䠄を示するので4個の 空气ブレー作

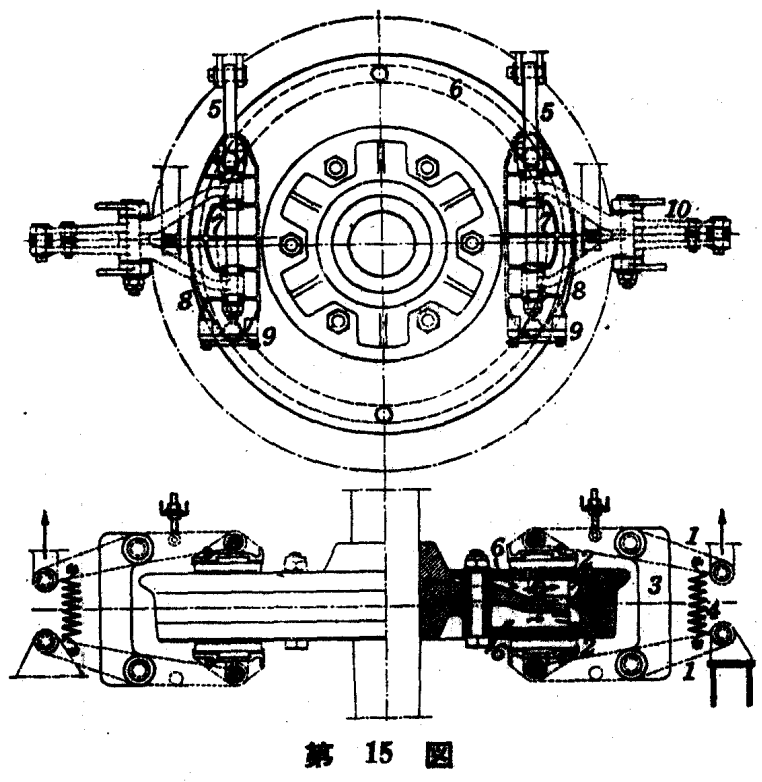

るカる通常のタイヤ・ブレーキに较べて小さくなり、且 ブ レーキの碰覃も少いといふ特曼がある。第15 因は本動輯に つけたブレーキ の作用部を示するので、車鮦の两面に取付

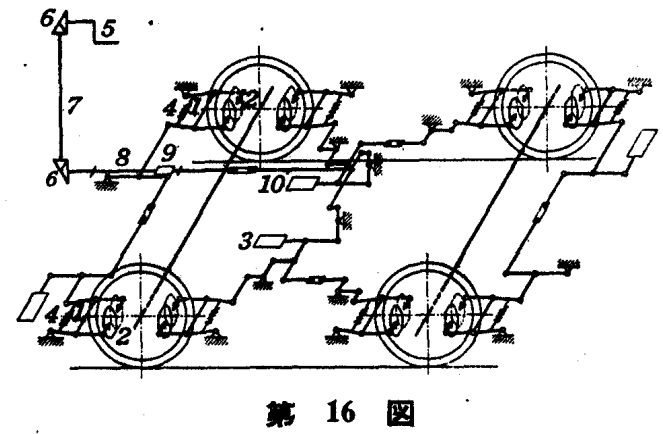

シリンダに依て各車輪にブレーキが卦けられる。野作并 6勿既合車に取付けてある。

本裝㳗の 制助力は車輪周に加はるものと換算して空車の 瀻合 $27 \%$ を示し、冈板への王力は $1 \cdot 75 \mathrm{~kg} / \mathrm{cm}^{2}$ に及んでる

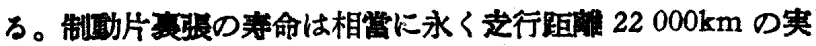

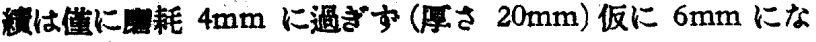
る迄使用出来るとして優に $75000 \mathrm{~km}$ を保つことが出来る。 現在までの実地成䋲によれば充分に满足すべきものであると のことである。

(岡田)

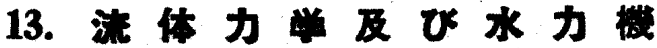

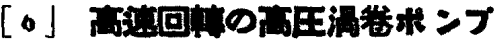

[V.D.I., Z.*, 1938-7-23, Bd. 82, Nr. 30 頁 893 894, 困 1] E．Beck の「一段高圧ポンプの可能性に関する研究」と いふ論女によれば高圧の 瀜ボンプに於ては普通行ふ様に

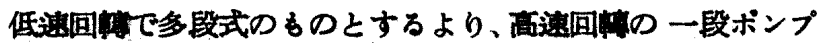
とする方が高い数躬を举げることが出来るといはれ、6000 $\mathrm{rev} / \mathrm{mn}$ から $20000 \mathrm{rev} / \mathrm{mn}$ で埸程が $600 \mathrm{~m}$ から $1000 \mathrm{~m}$ といふやうな高速离压の ポンブが洘へられてるる。

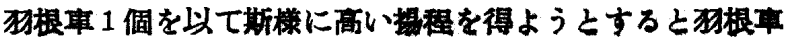

の入口に於て葍だしい壮力差が起りこの附近にキャビテーシ ョンが起ろから、これを防ぐためには旸根車の回㯖数と水溫 に應じて邪根車に流入する水に $5 \mathrm{~atm}$ から $20 \mathrm{~atm}$ 位の予圧 を加へてやる必要がある。この圧力は特別の 予压ボンブで 與へなければならぬが、この 予区ポンプ に適雬な每分の回 中数は 主ポンブの回艘数より遥に少い。

Beckの理論に良て 予圧ボンブ を持つた一つの 高圧渦绻 ポンプ が計萛設㖕された。この ポンプは Spannhake 数授 に依てその可能性を示されたやうに、予圧ボンブの雅桹の

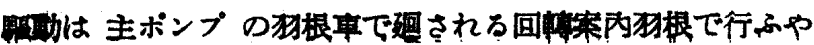

昭租 14 年 1 月] 